J. Japan. Soc. Hort. Sci. 50(1) : 60-65. 1981.

\title{
Nutritional Relationship between Nitrogen and Sulfur in Cabbage (Brassica oleracea L. var. capitata L.)
}

\author{
Tetsuo Hara, Koji Sugimoto and Yoji Sonoda \\ Faculty of Agriculture, Gifu University, \\ Kakamigahara, Gifu 504
}

\begin{abstract}
Summary
Cabbage plants were grown in nutrient solutions containing 3 levels of nitrogen (as $\mathrm{NaNO}_{3} ; 10,100,500 \mathrm{ppm} \mathrm{N}$ ) combined with 3 levels of sulfur (as $\mathrm{Na}_{2} \mathrm{SO}_{4} ; 1$, $10,50 \mathrm{ppm} \mathrm{S}$ ), and the effects of the nitrogen and sulfur supply on the growth and the chemical composition of the plants were studied.

Total plant dry weight increased with an increase in the S supply when the $\mathrm{N}$ supply was 100 or $500 \mathrm{ppm}$, but was always small when the $\mathrm{N}$ supply was $10 \mathrm{ppm}$, irrespective of the $S$ supply. The highest cabbage-head yield was obtained at $100 \mathrm{ppm}$ $\mathrm{N}$ and $10 \mathrm{ppm} \mathrm{S}$, while little cabbage-head yield was obtained at $10 \mathrm{ppm} \mathrm{N}$ or $1 \mathrm{ppm}$ $\mathrm{S}$. The total $\mathrm{N}$ content in each organ increased greatly with an increase in the $\mathrm{N}$ supply and decreased slightly with an increase in the $S$ supply. The total $S$ content incresased greatly with an increase in the S supply and decreased slightly with an increase in the $\mathrm{N}$ supply. A total $\mathrm{N}$ content below $2 \%$ and a total $\mathrm{S}$ content below $0.1 \%$ on a dry basis in the outer leaves was found to be insufficient for cabbagehead formation. Cabbage-head development was most efficiently when the total N/S content ratio was between 10 and 20 , although the ratio fluctuated widely, from 4 to 235. N-deficient plants contained less sugars and more starch as compared with the $\mathrm{N}$ - and S-sufficient plants. S-deficient plants contained less sugars and $80 \%$ ethanol-insoluble protein $\mathrm{N}$ and more $80 \%$ ethanol-soluble non-protein $\mathrm{N}$.
\end{abstract}

\section{Introduction}

Sulfur is a macronutrient for higher plants, but the number of studies on sulfur nutrition in crop plants in Japan seems smaller than that on the functions of other nutrients, because sulfur deficiencies in crop plants do not occur widely and frequently: the necessity of studying sulfur nutrition has been small. However, increased incidences of sulfur deficiency of lowland rice in foreign countries have been reported recently, since a larger amount of sulfur-free fertilizers are being produced and used in the world (11). When sulfur-free fertilizers are applied exclusively to crop fields in Japan, sulfur deficiencies may occur in the future. It is thus important to establish guidelines for diagnosing sulfur deficiencies in each crop plant.

Sulfur nutrition in a plant is closely associated with nitrogen nutrition, because both

\footnotetext{
Received for publication May 23, 1980.
}

nutrients are components of proteins. Sulfur deficient plants contain larger amounts of nitrogen, especially non-protein nitrogen, than sulfur-sufficient plants, because protein synthesis is inhibited by lack of sulfur(6). It is reasonable to consider both the nitrogen and the sulfur supply in diagnosing sulfur deficiencies. Because of this, in some crop plants the N/S content ratio has been proposed as a better indicator of sulfur deficiency than the sulfur content $(5,10)$.

The present study was conducted to determine the interaction between nitrogen and sulfur uptake in cabbage plants, and the subsequent effect of this interaction on cabbage growth and cabbage-head formation.

\section{Materials and Methods}

Seeds of Haruhikari No.1 were sown in vermiculite in a green house, and irrigated with tap water. At 19 days after sowing, the seedlings were transplanted to 4 liter pots 
containing a nitrogen- and sulfur-free culture solution. The composition of the culture solution, in ppm, was $20 \mathrm{P}, 50 \mathrm{~K}, 100 \mathrm{Ca}$ and $25 \mathrm{Mg}$. These nutrients were added in the forms of $\mathrm{Na}_{2} \mathrm{HPO}_{4}, \mathrm{KCl}, \mathrm{CaCl}_{2}$ and $\mathrm{MgCl}_{2}$, respectively. All micronutrients were also added to the culture solution(3). One hundred ppm $\mathrm{N}$ as $\mathrm{NaNO}_{3}$, and 10 ppm $\mathrm{S}$ as $\mathrm{Na}_{2} \mathrm{SO}_{4}$, were added uniformly before the nitrogen and sulfur treatments. At 29 days after sowing, 3 levels of nitrogen (10, 100, $500 \mathrm{ppm} \mathrm{N}$ ) combined with 3 levels of sulfur $(1,10,50$ ppm S) were established, using three replications. The culture solution was aerated occasionally and renewed every 7 days, and the $\mathrm{pH}$ adjusted to 5.5 using $2 \mathrm{~N} \mathrm{HCl}$ and $2 \mathrm{~N}$ $\mathrm{NaOH}$. Cabbage-head formation in healthy plants started about 60 days after sowing. All the plants were harvested simultaneously at 96 days after sowing, and separated into inner leaves (forming each cabbage-head), outer leaves, stems, and roots. These organs were dried at $70^{\circ} \mathrm{C}$, weighed, and milled for chemical analysis.

Total $\mathrm{N}$ in the plant samples was determined by the Gunning's method; insoluble $\mathrm{N}$ in the residue from $80 \%$ ethanol extractions of the samples was determined by the Kjeldahl method. Total $\mathrm{N}$ minus insoluble $\mathrm{N}$ is soluble N. Total S, insoluble $\mathrm{S}$ and soluble $\mathrm{S}$ were determined similarly by the turbidimetric method(8). Total sugar and crude starch were determined by the colorimetric anthron-sulfuric acid method, using glucose as a standard; sugar was extracted using $80 \%$ ethanol, and crude starch was extracted from the resulting residue using $4.6 \mathrm{~N} \mathrm{HClO}_{4}(4)$.

\section{Results}

\section{Plant dry weight.}

The total plant dry weight was more or less the same, and small when the nitrogen supply was $10 \mathrm{ppm}$ (Fig. 1). When the nitrogen supply was 100 or $500 \mathrm{ppm}$, the total plant dry weight increased with an increase in the sulfur supply from 1 to $50 \mathrm{ppm}$. When the sulfur supply was 10 or $50 \mathrm{ppm}$, the total plant dry weight (ordered by nitrogen supply) was in the following order : 100>500>10 ppm N. There was a positive correlation between the total dry weight and the dry weight of each organ. The highest cabbagehead yield (i.e. dry weight of head leaves) was obtained at $100 \mathrm{ppm} \mathrm{N}$ and $10 \mathrm{ppm} \mathrm{S}$,

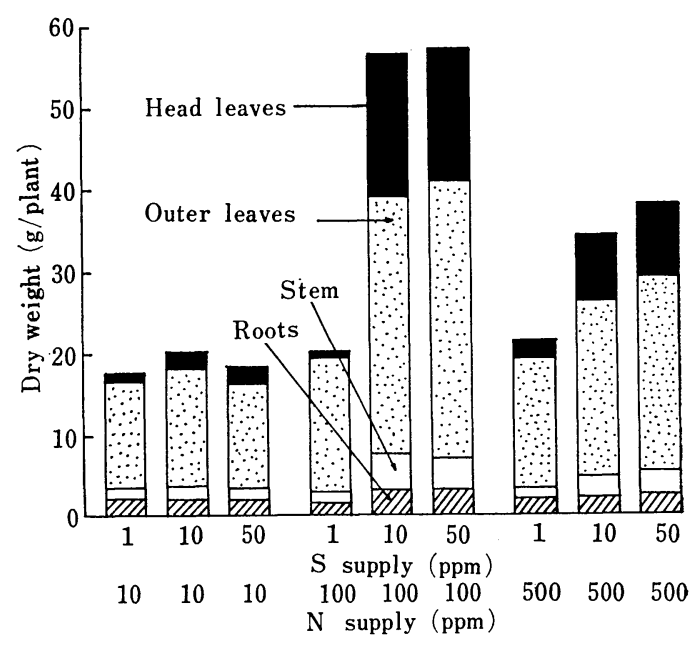

Fig. 1. Effects of the nitrogen and sulfur supply on the dry weight of each organ.

Table 1. Effects of the nitrogen and sulfur supply on the total $\mathrm{N}$ content (\% on a dry wt basis) in each organ.

\begin{tabular}{c|c|c|c|c|c}
\hline $\begin{array}{c}\text { N supply } \\
\text { (ppm) }\end{array}$ & $\begin{array}{c}\text { S supply } \\
\text { (ppm) }\end{array}$ & $\begin{array}{c}\text { Head } \\
\text { leaves }\end{array}$ & $\begin{array}{c}\text { Outer } \\
\text { leaves }\end{array}$ & Stem & Roots \\
\hline 10 & 1 & 3.66 & 1.76 & 1.47 & 2.84 \\
10 & 10 & 3.02 & 1.51 & 1.44 & 2.52 \\
10 & 50 & 2.09 & 1.37 & 1.25 & 2.43 \\
100 & 1 & 5.43 & 4.12 & 3.41 & 3.96 \\
100 & 10 & 3.72 & 3.69 & 2.84 & 3.69 \\
100 & 50 & 3.63 & 3.58 & 2.54 & 3.17 \\
500 & 1 & 6.26 & 4.71 & 3.48 & 4.62 \\
500 & 10 & 4.59 & 4.33 & 3.44 & 4.00 \\
500 & 50 & 4.51 & 4.14 & 3.33 & 3.85 \\
\hline
\end{tabular}

Table 2. Effects of the nitrogen and sulfur supply on the total S content ( $\%$ on a dry wt basis) in each organ.

\begin{tabular}{c|c|c|c|c|c}
\hline \hline $\begin{array}{c}\text { N supply } \\
\text { (ppm) }\end{array}$ & $\begin{array}{c}\text { S supply } \\
\text { (ppm) }\end{array}$ & $\begin{array}{c}\text { Head } \\
\text { leaves }\end{array}$ & $\begin{array}{c}\text { Outer } \\
\text { leaves }\end{array}$ & Stem & Roots \\
\hline 10 & 1 & 0.26 & 0.03 & 0.03 & 0.13 \\
10 & 10 & 0.38 & 0.31 & 0.22 & 0.50 \\
10 & 50 & 0.46 & 0.38 & 0.29 & 0.59 \\
100 & 1 & 0.04 & 0.02 & 0.02 & 0.10 \\
100 & 10 & 0.08 & 0.20 & 0.09 & 0.23 \\
100 & 50 & 0.13 & 0.36 & 0.18 & 0.32 \\
500 & 1 & 0.03 & 0.02 & 0.02 & 0.10 \\
500 & 10 & 0.10 & 0.17 & 0.07 & 0.21 \\
500 & 50 & 0.12 & 0.34 & 0.15 & 0.33 \\
\hline
\end{tabular}


Table 3. Effects of the nitrogen and sulfur supply on the total N/S content ratio, the soluble $\mathrm{N}$ or $\mathrm{S}$ content, the insoluble $\mathrm{N}$ or $\mathrm{S}$ content, and the insoluble N/S content ratio of the outer leaves.

\begin{tabular}{c|c|r|c|c|c|c|c}
\hline \hline $\begin{array}{c}\text { N supply } \\
(\mathrm{ppm})\end{array}$ & $\begin{array}{c}\text { S supply } \\
(\mathrm{ppm})\end{array}$ & $\begin{array}{c}\text { Total } \\
\mathrm{N} / \mathrm{S}\end{array}$ & $\begin{array}{c}\text { Soluble N } \\
(\%)\end{array}$ & $\begin{array}{c}\text { Insoluble N } \\
(\%)\end{array}$ & $\begin{array}{c}\text { Soluble S } \\
(\%)\end{array}$ & $\begin{array}{c}\text { Insoluble S } \\
(\%)\end{array}$ & $\begin{array}{c}\text { Insoluble } \\
\mathrm{N} / \mathrm{S}\end{array}$ \\
\hline 10 & 1 & 59 & 0.83 & 0.93 & 0.01 & 0.02 & 47 \\
10 & 10 & 5 & 0.52 & 0.99 & 0.20 & 0.11 & 9 \\
10 & 50 & 4 & 0.39 & 0.98 & 0.22 & 0.16 & 6 \\
100 & 1 & 206 & 2.30 & 1.82 & $\operatorname{tr}$ & 0.02 & 91 \\
100 & 10 & 18 & 1.11 & 2.58 & 0.07 & 0.13 & 20 \\
100 & 50 & 10 & 1.05 & 2.53 & 0.18 & 0.18 & 14 \\
500 & 1 & 235 & 2.89 & 1.82 & $\operatorname{tr}$ & 0.02 & 91 \\
500 & 10 & 25 & 1.45 & 2.88 & 0.05 & 0.12 & 24 \\
500 & 50 & 12 & 1.32 & 2.82 & 0.13 & 0.20 & 14 \\
\hline
\end{tabular}

while little cabbage-head yield was obtained at $10 \mathrm{ppm} \mathrm{N}$ or $1 \mathrm{ppm} \mathrm{S}$. All the plants at 100 or $500 \mathrm{ppm} \mathrm{N}$ and $1 \mathrm{ppm} \mathrm{S}$ showed symptoms of sulfur deficiency. Sulfur-deficient leaves turned purple, and the marginal part of each leaf curled inward like a cup, after which necrotic areas developed between the leaf-veins; leaves with severe necrosis gradually fell off.

Total $N$ and $S$ contents in the plants.

The total $\mathrm{N}$ content in each organ increased greatly with an increase in the nitrogen supply, and decreased slightly with an increase in the sulfur supply (Table 1). Among the organs, the head leaves had the highest total $\mathrm{N}$ concent, followed by the roots when the nitrogen supply was $10 \mathrm{ppm}$, and followed by the outer leaves when the nitrogen supply was 100 or $500 \mathrm{ppm}$.

The total S content in each organ increased greatly with an increase in the sulfur supply, and decreased slightly with an increase in the nitrogen supply (Table 2). The roots tended to have the highest total $\mathrm{S}$ content among the organs independent of the nitrogen supply, except that, at $10 \mathrm{ppm} \mathrm{N}$ and $1 \mathrm{ppm} \mathrm{S}$, the head leaves had the highest S concent.

Total N/S and insoluble N/S content ratio in the outer leaves.

From the results of the total $\mathrm{N}$ and $\mathrm{S}$ contents, the total N/S content ratio of the outer leaves was computed (Table 3 ). The total N/S content ratio increased with an increase in the nitrogen supply and decreased with an increase in the sulfur supply.
Both soluble $\mathrm{N}$ and insoluble $\mathrm{N}$ contents in the outer leaves increased with an increase in the nitrogen supply (Table 3). The soluble $\mathrm{N}$ content was quite high at $1 \mathrm{ppm} \mathrm{S}$ and decreased with an increase in the sulfur supply, while the insoluble $\mathrm{N}$ content remained at a constant level at each leavel of the nitrogen supply with the exception of a low value at $1 \mathrm{ppm} S$ and 100 or $500 \mathrm{ppm} \mathrm{N}$. Soluble $\mathrm{S}$ and insoluble $\mathrm{S}$ contents increased with an increase in the sulfur supply, and the increase in the soluble $\mathrm{S}$ content seemed larger than in the insoluble $\mathrm{S}$ content. Both contents decreased with an increase in the nitrogen supply. The insoluble N/S content ratio increased with an increase in the nitrogen supply and decreased with an increase in the sulfur supply. This change was similar to but smaller than that in the total N/S content ratio.

Total Sugar and crude starch contents in the outer leaves.

The total sugar content in the outer leaves was higher in plants grown at $100 \mathrm{ppm} \mathrm{N}$ than those grown at 10 or $500 \mathrm{ppm} \mathrm{N}$ (Table 4). At each level of the nitrogen supply, the total sugar content was lower at $1 \mathrm{ppm}$ $\mathrm{S}$ than at 10 or $50 \mathrm{ppm} \mathrm{S}$. The crude starch content was higher at $10 \mathrm{ppm} \mathrm{N}$ than at 100 or $500 \mathrm{ppm} \mathrm{N}$, and was unaffected by the sulfur supply. The total carbohyrate (i.e. total sugar plus crude starch)/nitrogen content ratio $(\mathrm{Ch} / \mathrm{N}$ ratio) of the outer leaves decreased with an increase in the nitrogen supply, and became vary low when the sulfur supply was $1 \mathrm{ppm}$. 
Table 4. Effects of the nitrogen and sulfur supply on the total sugar content, the crude starch content, and the total carbohydrate/nitrogen content ratio $(\mathrm{Ch} / \mathrm{N}$ ratio) of the outer leaves.

\begin{tabular}{c|c|c|c|c|c}
\hline \hline \multirow{2}{*}{$\begin{array}{c}\text { Nupply } \\
\text { (ppm) }\end{array}$} & $\begin{array}{c}\text { S supply } \\
\text { (ppm) }\end{array}$ & $\begin{array}{c}\text { Total } \\
\text { sugar }\end{array}$ & $\begin{array}{c}\text { Crude } \\
\text { starch }\end{array}$ & $\begin{array}{c}\text { Total } \\
\text { carbohy- } \\
\text { drate }\end{array}$ & $\begin{array}{c}\text { Ch/N } \\
\text { ratio }\end{array}$ \\
\cline { 3 - 5 } & & \multicolumn{2}{|c|}{$\begin{array}{c}\text { (glucose \% on a dry } \\
\text { basis) }\end{array}$} & \\
\hline 10 & 1 & 14.1 & 8.4 & 22.5 & 12.8 \\
10 & 10 & 20.2 & 7.6 & 27.8 & 18.4 \\
10 & 50 & 19.9 & 7.7 & 27.6 & 20.1 \\
100 & 1 & 16.0 & 3.1 & 19.1 & 4.6 \\
100 & 10 & 32.1 & 2.4 & 34.5 & 9.3 \\
100 & 50 & 31.3 & 2.5 & 33.8 & 9.4 \\
500 & 1 & 10.8 & 2.9 & 13.7 & 2.9 \\
500 & 10 & 16.4 & 2.3 & 18.7 & 4.3 \\
500 & 50 & 16.6 & 2.3 & 18.9 & 4.6 \\
\hline
\end{tabular}

\section{Discussion}

In order to see how nitrogen and sulfur levels in cabbage plants affect cabbage-head formation, the relationship between the cabbage-head yield and the total nitrogen and sulfur contents in the outer leaves was examined (Fig. 2). Plants grown at $100 \mathrm{ppm} \mathrm{N}$

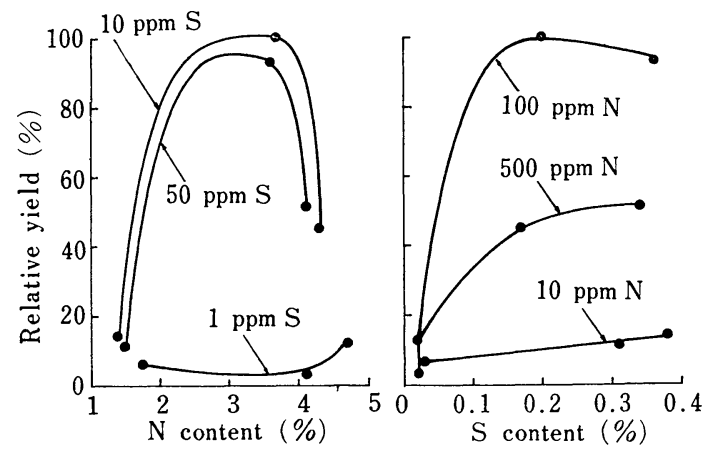

Fig. 2. Relationship between the cabbage-head yield and the total $\mathrm{N}$ or $\mathrm{S}$ content in the outer leaves.

and $10 \mathrm{ppm} \mathrm{S}$ were chosen as a basis for comparison because they gave the highest cabbage-head yield; the relative yield in Figure 2 is thus the percentage of the dry weight of the head leaves of each plant relative to that at $100 \mathrm{ppm} \mathrm{N}$ and $10 \mathrm{ppm} \mathrm{S}$. When the plants become dificient in sulfur due to the low sulfur supply, cabbage-head development does not occur. When the plants contain an adequate amount of nitrogen, cabbage-head yield increases with an increase in the nitrogen content up to about $3 \%$. A nitrogen content below $2 \%$ in the outer leaves is considered to be insufficient for cabbage-head formation, although nitrogen content varies with plant age even at this growth stage(2). Since nitrogen-deficient leaves have a low photosynthetic rate(9), the growth of head leaves depending on the photosynthates of the nitrogen-deficient outer leaves is undoubtedly reduced. A nitrogen content over $4 \%$ in the outer leaves also seems to inhibit cabbage-head formation. In this case cabbage-head development does not occur efficiently because the carbohydrate source is limited (Table 4) due to the low photosynthetic rate of nitrogen-excessive leaves(9). It is apparent that cabbage-head development occurs efficiently when the $\mathrm{Ch} / \mathrm{N}$ ratio is about 9 (Table 4). The cabbage-head of the nitrogen-excassive plants is sometimes deformed(2) or is not rigidly folded by the head leaves. When cabbage plants are supplied with a suitable level of nitrogen, about.100 ppm, cabbage-head yield increases with an increase in the sulfur content up to $0.2 \%$. It has been reported elsewhere(3) that a sulfur content lower than $0.04 \%$ in the outer leaves results in a $50 \%$ decrease in the cabbage-head yield. Nitrogen accumulates in the sulfur-deficient plants in the forms of low molecular nitrogen compounds such as nitrates, amides and amino acids( 7 ), because protein synthesis is inhibited. In fact, soluble $\mathrm{N}$ (which is considered to be composed of low molecular nitrogen compounds) accumulated, and insoluble $\mathrm{N}$ (which is considered to be composed of high molecular nitrogen compounds) decreased only a little in the sulfur-deficient leaves (Table 3). Impaired protein synthesis in sulfur-deficient leaves results in lowered production of chlorophyll, and thus in a low photosynthetic rate in the leaves(1). As a result, soluble sugar concentrations in sulfur-deficient plants decrease, as has been reported for corn plants(6).

There is a clear interaction between nitrogen and sulfur uptake by cabbage plants: The uptake of one nutrient causes a decrease in the uptake of the other nutrient and thus 
changes the total $\mathrm{N} / \mathrm{S}$ concent ratio to a greater extent. The total $\mathrm{N} / \mathrm{S}$ content ratio therefore changes so widely that the ratio does not seem to be useful for diagnosing sulfur nutrition of cabbage plants. It can be said however that it is desirable for cabbage plants to have a total $\mathrm{N} / \mathrm{S}$ content ratio between 10 and 20(3). The inosoluble N/S content ratio changes to a smaller extent than the total N/S content ratio, because the fluctuation of nitrogen and sulfur in the non-protein fraction is greater than in the protein fraction(10). The insoluble N/S content ratio may thus be a more reliable guideline for diagnosing sulfur nutrition of plants than the total N/S content ratio(7). However, we feel that percent $\mathrm{S}$ analysis is a simple, more reliable, and less costly (11) for crop plants whose pattern of sulfur nutrition with age has been determined.

\section{Literature Cited}

1. Bottrill, D.E., J. V. Possingham, and P. E. KRIEDEMANN. 1970. The effect of nutrient deficiencies on photosynthesis and respiration in spinach. Plant and Soil 32:424-438.

2. HARA; T. and Y. SONODA. 1979. The role of macronutrients for cabbage-head formation. Preliminary report and I. Growth performance of a cabbage plant and potassium nutrition in the plant. Contribution to cabbagehead formation of nitrogen, phoshorus or potassium supplied at different growth stages. Soil Sci. Plant Nutr. 25 : 103-111.113120.

3. HARA, T. and Y.SONODA. 1981. The role of macr nutrients in cabbage-head fromation.
II. Contribution to cabbage-head formation of calcium, magnesium or sulfur supplied at different growth stages. Soil Sci. Plant Nutr. $27: 45-54$.

4. MaCCREADY, R. M., J. GugGolz, V. Silviera, and H.S. OWENS. 1950. Determination of sta $\mathrm{rch}$ and amylose in vegetables. Anal. Chem. $22: 1156-1158$.

5. RASMussen, P.E., R.E. RAMig, L. G. EKIN, and C. R. ROHDE. 1977. Tissue analyses guidelines for diagnosing sulfur deficiency in wheat. Plant and Soil $46: 153-163$.

6. Rendig, V. V., C. OpUTA, and E. A. МССомB. 1976. Effects of sulfur deficiency on nonprotein nitrogen, soluble sugars, and N/S ratios in young corn (Zea mays L.) plants. Plant and Soil $44: 423-437$.

7. Stewart, B. A. and L.K. Porter. 1969. Nitrogen-sulfur relationships in wheat (Triticum aestivum L.), corn (Zea mays), and beans (Phaseolus vulgaris). Agron. J. 61 : $267-271$.

8. TABATABAI, M. A. and J. M. BREMNER. 1970. A simple turbidimetric method of determining total sulfur in plant materials. Agron. J. $62: 805-806$.

9. TANAKA, A. and T. HARA. 1970. Nutriophysiological studies on the photosynthetic rate of the leaf. I. Effect of nitrogen status on the photosynthetic rate in the corn plant. J. Sci. Soil Manure, Japan $41: 502-508$. (In Japanese).

10. WESTERMANN, D. T. 1975. Indexes of sulfur deficiecy in alfalfa. II. Plant analyses. Agron. J. $67: 265-268$.

11. Yoshida, S. and M. R. Chaudhry. 1979. Sulfur nutrition of rice. Soil Sci. Plant Nutr. $25: 121-134$.

\section{キャベッにお拈ける窒素と硫黄栄養の関連性について}

原徹夫・杉本孝司・園田洋次

(岐皁大学農学部)

\footnotetext{
摘要

春光り一号カンランの幼植物を 3 段階の $\mathrm{NO}_{3}-\mathrm{N}$ 濃度 $(10,100,500 \mathrm{ppm} \mathrm{N})$ と $\mathrm{SO}_{4}-\mathrm{S}$ 濃度 $(1,10,50 \mathrm{ppm}$ S) の組合せによる 9 種類の培養液で 67 日間栽培し, これらの処理が植物の生育と化学組成におよぼす影響を 調查した。

$\mathrm{N}$ 供給量が 100 か $500 \mathrm{ppm}$ の場合には S 供給量の増 加にともない植物乾物重は上昇したが， N供給量が 10 $\mathrm{ppm}$ の場合には $\mathrm{S}$ 供給量に関係なく植物乾物重は低か った. 最高の結球収量は $100 \mathrm{ppm} \mathrm{N} \cdot 10 \mathrm{ppm} \mathrm{S}$ 区で得ら れ, $1 \mathrm{ppm} \mathrm{S}$ か $10 \mathrm{ppm} \mathrm{N}$ の場合にはほとんど結球収量
} 
よ得られなかった．植物の全 $\mathrm{N}$ 含有率は $\mathrm{N}$ 供給量の増加 で大きく上昇し， $\mathrm{S}$ 供給量の増加でわずかに低下した。 直物の全 $\mathrm{S}$ 含有率は $\mathrm{S}$ 供給量の増加で大きく上昇し, $\mathrm{N}$ 共給量の增加でわずかに低下した．結球収量と外葉の全 、あるいは全 S 含有率との関係より，全N含有率が $2 \%$ 认下か全 $\mathrm{S}$ 含有率が $0.1 \%$ 以下の場合には高収量は得ら
れないと考えられた。全 N/S 含有率比は 4 から 235 ま で変動したが，10２0 の範团にあるときに結球は効率 良く肥大した．N欠乏植物では糖含有率が低く，また $\mathrm{S}$ 欠乏植物では糖含有率と蛋白 ( $80 \%$ エタノール不溶) $\mathrm{N}$ 含有率が低く，非蛋白 $(80 \%$ エタノール可溶） $\mathrm{N}$ 含 有率がきわめて高かった。 